\title{
CAN A BIGGIE GET MORE? THE ROLE OF REGIONAL CENTRES IN THE PROCESS OF ABSORPTION OF EUROPEAN FUNDS IN POLISH VOIVODESHIPS
}

\author{
Paweł Churski, Robert Perdał, Tomasz Herodowicz \\ Institute of Socio-Economic Geography and Spatial Management \\ Adam Mickiewicz University in Poznań \\ Dzięgielowa 27, 61-680 Poznań: Poland \\ chur@amu.edu.pl,r.perdal@amu.edu.pl, herod@amu.edu.pl
}

\begin{abstract}
This paper seeks to determine the share of Polish regional centres in the absorption of European funds as compared with their regional surroundings. The analysis covered the years 2004-2013 and embraced 18 cities functioning as regional capitals and 16 voivodeships. The research proceeded in three stages. In the first one, the position of the regional capitals was determined against the level of socio-economic development of the country's poviats. Stage two was devoted to the magnitude and absorption structure of European means in the regional centres. The third part of the procedure covered identification of the place of the regional centres in the process of absorption of EU funds in voivodeships.
\end{abstract}

Keywords: regional centres, region, absorption of EU funds, Poland.

\section{Introduction}

Regional centres are the places of spatial agglomeration of the population and economic entities accompanied by a branch-related concentration of economic activity (Jacobs 1969; Amiti \& Cameron 2007; Baum-Snow \& Pavan 2012; Behrens et al. 2014; Duranton 2014; Mallach 2014). As areas of development polarisation, they are of special interest to urban policy, both in its internal and external dimensions (Foreman-Peck \& Gripaios 1977; Townsend 1977; Reshaping Economic Geography 2009; Hidle \& Leknes 2014; Krajowa Polityka Miejska 2015). The changing paradigm of the cohesion policy - departing from equalisation in favour of efficiency - serves to justify the developmental intervention directed to regional centres, which in the equalisation model were perceived as growth poles requiring allocation of smaller funds (Bachtler 2001; Soja 2010; Storper 2011). This switch is justified by reinforcing the impact of regional centres on their surroundings, which means paying more attention to the external effect of urban policy, especially by strengthening territorial cohesion (Zaucha \& Komornicki 2015). It is however also justified by the need to implement measures that improve standards of living of the residents of regional centres, efficiency of which is relatively the 
highest in the areas with high population density, as pointed out by Rodríguez-Pose and Garcilazo (2015). Those measures should be adjusted to specific needs of such areas as determined by their territorial capitals, in accordance with the assumptions of a place-based policy (Camagni 2008; Barca 2009). Regrettably, the development intervention supported by EU means has so far turned out to be inefficient (Maynou et al. 2014). This means that it is necessary to continue research in this field, which justifies undertaking the present analysis.

This paper seeks to determine the role of Polish regional centres in the absorption of European funds in relation to their regional surroundings. This goal is sought in a research procedure verifying three hypotheses:

1. The capitals of Polish voivodeships, irrespective of their development-related position in the country, are the areas displaying the highest level of socio-economic development in the intra-regional system.

2. A greater part of total EU funds at the regional level in Poland is allocated to the voivodeship capitals.

3. There are significant differences in the concentration of projects co-financed from EU funds in regional centres in terms of programming periods, kinds of funds, operational programmes, and categories of intervention.

The analysis embraced 18 regional centres that are capitals of the 16 Polish voivodeships (Kujavia-Pomerania and Lubuska Land have two regional centres each). The temporal range embraced the years 2004-2015, which correspond to the period of the first two budgetary perspectives after Poland had joined the European Union (EU): 2004-2006 and 2007-2013 ${ }^{1}$. The research procedure consisted of four stages. In the first one, the distance-from-standard method and cluster analysis were employed to determine the position of the regional centres on the scale of socio-economic development, on the basis of a prepared multi-dimensional geographical observation base. In the second one, the use was made of the EU Subsidies Map database of the Ministry of Infrastructure and Development to perform an analysis of differences in the size and structure of European projects carried out by beneficiaries in the regional centres in Poland. The third stage involved determination of the position of regional centres in the absorption of EU funds in relation to their regional surroundings. Using the share indices and values of the location quotient $(L Q)^{2}$, the concentration of EU-supported projects in the regional centres (their number, value and structure) was determined in terms of programming periods, kinds of funds, operational programmes, and intervention categories. In the last, fourth stage, correlation and regression analyses were employed to establish the relation between the amount of the EU funds absorbed by the regional centres and their levels of socio-economic development. The paper ends with conclusions presenting the degree of verification of the initial research hypotheses and with recommendations for development policy practice that follow from the study.

\footnotetext{
1 Implementation of Community intervention in the 2007-2013 programming period ends formally in 2015.

2 The location quotient - a measure of the concentration of a feature in an area (\% of the total value of the feature) in relation to population concentration in this area (\% of total population).
} 


\section{Place of the regional centres on the scale of socio-economic development}

The position of Polish regional centres on the scale of socio-economic development in the poviat system was determined in four stages. The first one involved the creation of a geographical observation base containing all indices determinable on the basis of data from the Local Data Bank of the Central Statistical Office (GUS) for the years 2004 and 2013. In effect, two 61 × 379 matrices were produced (indices $x$ poviats). In the next stage, these matrices were reduced by selecting diagnostic variables using a correlation matrix and critical values of Pearson's linear correlation coefficient (Hellwig 1981; Nowak 1990). The variables were reduced when the value of the coefficient of correlation between the indices examined was high, statistically significant and, additionally, when there was a correlation between the indices and not only covariance. As a result of the reduction, $15 \times 379$ matrices were obtained (in both years the same set of variables was employed). In the third stage, the poviats were arranged linearly on the scale of socio-economic development using the method of distance from the development standard (Hellwig 1968; Suchecki 2010). The set of 15 indices was then standardised. On the basis of the standardised variables, a development standard and an anti-standard were determined:

- standard: $z_{0}=\left[z_{01}, z_{02}, \ldots z_{0 m}\right] \rightarrow z_{0 j}= \begin{cases}\max _{i}\left\{z_{i j}\right\} & \text { for the stimulant } \\ \min _{\mathrm{i}}\left\{z_{i j}\right\} & \text { for the destimulant }\end{cases}$

- anti-standard: $z_{-0}=\left[z_{-01}, z_{-02}, \ldots z_{-0 m}\right] \rightarrow z_{-0 j}= \begin{cases}\min _{\mathrm{i}}\left\{z_{i j}\right\} & \text { for the stimulant } \\ \max _{\mathrm{i}}\left\{z_{\mathrm{ij}}\right\} & \text { for the destimulant }\end{cases}$

Next, the Euclidean distance of each poviat $i$ from the development standard was calculated:

$$
d_{i 0}=\sqrt{\sum_{j=1}^{m}\left(z_{i j}-z_{0 j}\right)^{2}}
$$

The last step of the third stage was determination of a synthetic development measure for each poviat $i$ :

$$
v_{i}=1-\frac{d_{i 0}}{d_{0}} ; v_{i} \in\langle 0 ; 1\rangle
$$

where $d_{0}$ is the Euclidean distance between the development standard and its anti-standard.

The fourth and last stage involved establishing the classes of poviats by their level of socioeconomic development. The classes of high, average and low levels of socio-economic development were determined with the help of cluster analysis using the $k$-means algorithm (where $k=3$ ). This is an iterative-optimisation method of non-hierarchical grouping in which the division of a set is conducted until its intra-group variance is minimised and its inter-group variance is maximised (Mac Queen 1966; Chudzik \& Karoński 1979).

The above procedure was also applied when classifying the regional centres only and exclusively in the group of those 18 cities. This allowed identifying the internal differences within the group without reference to their position in relation to all poviats in Poland. This procedure is grounded by the method employed to measure the level of socio-economic development, which enabled the positioning of the units under study against the hypothetical ideal units with the greatest (standard) or the smallest (anti-standard) values of the indices examined (all poviats or just the 18 cities). 


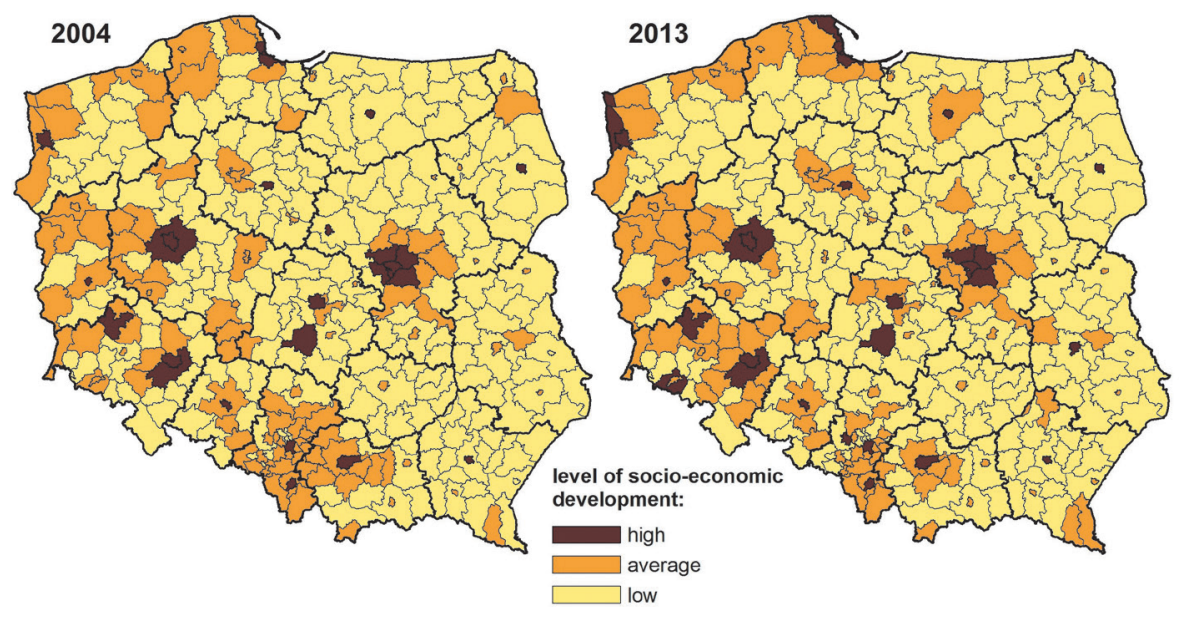

Figure 1. Socio-economic development level of the regional centres in relation to poviats in Poland in the years 2004 and 2013

Source: own compilation on the basis of data from the GUS (Central Statistical Office) Local Data Bank.

The analysis of socio-economic development level of the regional centres against that of poviats revealed wide differences among those units. In 2013, a mere $7.9 \%$ of poviats showed a high level of socio-economic development (a $1 \%$ increase over 2004). This group includes the largest urban agglomerations (the regional centres and non-municipal poviats surrounding them), smaller towns that performed the function of voivodeship capitals before the 1999 reform of the administrative division, and poviats in which large enterprises, mostly mining and power engineering ones, are located (Polkowice, Bełchatów and Zgorzelec) (Fig. 1, Tab. 1). In 2013, 14 regional centres showed a high level of socio-economic development and only three an average one (Bydgoszcz, Gorzów Wielkopolski and Kielce). In comparison with 2004, only Lublin changed its position here, moving from average to high class. It should be noted that the change that took place in the years 2004-2013 involved only a slight improvement in the socio-economic situation of poviats in Poland. In 2013, the proportion of poviats at low level of socio-economic development was $61.2 \%$, which means that over the decade the number of poviats in this class dropped by less than $1.6 \%$. Thus, the share of poviats at an average level of socio-economic development varied between $30.3 \%$ and $30.9 \%$. Poviats at very low and low level of socio-economic development can be found in each voivodeship, usually in its peripheral parts. This concerns both the years 2004 and 2013, however more poviats at the lowest development level were identified in the eastern voivodeships (Lublin, Warmia-Mazuria, Świętokrzyska Land, Podlasie, Subcarpathia) as well as in Łódź voivodeship and Kujavia-Pomerania. The fact that the distance between poviats at the highest and the lowest level of socio-economic development had decreased over the study period is worth emphasizing. This resulted from relative lowering (against the development standard) of the socio-economic development level of the former, i.e. Warsaw, and not increasing the development level of the latter. In 2013, the synthetic index of the development level $\left(v_{i}\right)$ for Warsaw was 0.535, and in 2004, 0.611. In turn, in 2013 the lowest development level was found in the Kętrzyn poviat (Warmia-Mazuria voivodeship), where $v=0.091$, whereas in 2004 in Szydłowiec poviat (nota bene in Mazovia), at $v=0.092$. In the group of cities being the voivodeship centres, differences in the level of socio-economic development 
are also considerable withthe tendency of change is for the distance between them and Warsaw to decrease. In 2013, index $v$ for Warsaw was 0.535 , and for the next city, Wrocław, 0.360, while in 2004 Warsaw accounted for $v=0.611$ and the susequent city, Poznań, reached $v=0.358$. Thus, the distance separating Warsaw from the next city in the ranking declined from 0.21 to 0.18 . In the remaining cases, the differences among voivodeship cities were not as high as presented above (Tab. 1).

Table 1. Level of socio-economic development of the regional centres in Poland in the years 2004-2013

\begin{tabular}{|c|c|c|c|c|c|c|c|c|c|c|c|c|c|c|c|c|}
\hline \multirow{3}{*}{ City } & \multicolumn{8}{|c|}{2004} & \multicolumn{8}{|c|}{2013} \\
\hline & \multicolumn{4}{|c|}{$\begin{array}{l}\text { in relation to } \\
379 \text { poviats }\end{array}$} & \multicolumn{4}{|c|}{$\begin{array}{c}\text { in relation to } \\
18 \text { cities }\end{array}$} & \multicolumn{4}{|c|}{$\begin{array}{l}\text { in relation to } \\
379 \text { poviats }\end{array}$} & \multicolumn{4}{|c|}{$\begin{array}{c}\text { in relation to } \\
18 \text { cities }\end{array}$} \\
\hline & $v_{i}$ & $\mathbf{R}$ & K & $\% \max$ & $v_{i}$ & $\mathbf{R}$ & K & $\% \max$ & $v_{i}$ & $\mathbf{R}$ & K & $\% \max$ & $v_{i}$ & $\mathbf{R}$ & $\mathrm{K}$ & $\%$ ma \\
\hline Białystok & .252 & 25 & W & 41.2 & 0.225 & 13 & $\mathrm{~N}$ & 36.2 & 0.238 & 25 & W & 44.5 & 0.213 & 15 & $\mathrm{~N}$ & 33.6 \\
\hline Bydgoszcz & 216 & 51 & $\mathrm{P}$ & 35.3 & 0.145 & 18 & $\mathrm{~N}$ & 23.4 & 0.207 & 38 & $\mathrm{P}$ & 38.7 & 0.173 & 17 & $\mathrm{~N}$ & 27.4 \\
\hline Gdańsk & 314 & 8 & W & 51.3 & 0.349 & 7 & $P$ & 56.1 & 0.308 & 5 & W & 57.6 & 0.394 & 5 & $\mathrm{P}$ & 62.2 \\
\hline Gorzów Wlkp. & 0.226 & 40 & $P$ & 37.0 & 0.222 & 14 & $\mathrm{~N}$ & 35.7 & 0.200 & 44 & $P$ & 37.5 & 0.220 & 14 & $\mathrm{~N}$ & 34.6 \\
\hline Katowice & 0.345 & 6 & W & 56.5 & 0.341 & 9 & $P$ & 54.8 & 0.287 & 7 & W & 53.6 & 0.339 & 7 & $P$ & 53.5 \\
\hline Kielce & 0.217 & 50 & $P$ & 35.5 & 0.182 & 16 & $\mathrm{~N}$ & 29.3 & 0.211 & 36 & $\mathrm{P}$ & 39.4 & 0.204 & 16 & $\mathrm{~N}$ & 32.1 \\
\hline Cracow & 0.372 & 3 & W & 60.8 & 0.379 & 3 & $P$ & 61.0 & 0.340 & 4 & W & 63.6 & 0.428 & 4 & W & 67.5 \\
\hline Lublin & .240 & 29 & $P$ & 39.3 & 0.220 & 15 & $\mathrm{~N}$ & 35.4 & 0.269 & 9 & W & 50.3 & 0.288 & 13 & $P$ & 45.4 \\
\hline Łódź & 0.278 & 15 & W & 45.5 & 0.175 & 17 & $\mathrm{~N}$ & 28.1 & 0.247 & 21 & W & 46.2 & 0.159 & 18 & $\mathrm{~N}$ & 25.1 \\
\hline Olsztyn & 0.300 & 10 & W & 49.1 & 0.368 & 5 & $\mathrm{~N}$ & 59.1 & 0.250 & 18 & W & 46.8 & 0.319 & 9 & $P$ & 50.2 \\
\hline Opole & 0.265 & 18 & W & 43.4 & 0.344 & 8 & $\mathrm{~N}$ & 55.2 & 0.255 & 15 & W & 47.7 & 0.359 & 6 & $P$ & 56.6 \\
\hline Poznań & 0.397 & 2 & W & 64.9 & 0.473 & 2 & $P$ & 76.1 & 0.354 & 3 & W & 66.3 & 0.491 & 3 & W & 77.5 \\
\hline Rzeszów & 257 & 21 & W & 42.0 & 0.268 & 11 & $\mathrm{~N}$ & 43.0 & 0.267 & 11 & W & 49.9 & 0.336 & 8 & $P$ & 52.9 \\
\hline Szczecin & 0.263 & 19 & W & 43.0 & 0.269 & 10 & IN & 43.3 & 0.256 & 14 & W & 47.8 & 0.294 & 11 & $P$ & 46.3 \\
\hline Toruń & 0.252 & 26 & W & 41.2 & 0.250 & 12 & $\mathrm{~N}$ & 40.2 & 0.254 & 16 & W & 47.5 & 0.289 & 12 & $P$ & 45.6 \\
\hline Warsaw & 0.611 & 1 & W & 100.0 & 0.622 & 1 & W & 100.0 & 0.535 & 1 & W & 100.0 & 0.634 & 1 & W & 100.0 \\
\hline Wrocław & 0.358 & 4 & W & 58.6 & 0.375 & 4 & $P$ & 60.4 & 0.360 & 2 & W & 67.2 & 0.493 & 2 & W & 77.7 \\
\hline Zielona Góra & 0.281 & 14 & W & 45.9 & 0.361 & 6 & $\mathrm{~N}$ & 58.0 & 0.245 & 22 & W & 45.7 & 0.313 & 10 & $\mathrm{P}$ & 49.4 \\
\hline
\end{tabular}

Symbols: $v_{i}$-synthetic measure of socio-economic development; $\mathrm{R}$ - rank on scale of socio-economic development; $\mathrm{K}$ - level of socio-economic development: $\mathrm{W}$ - high, $\mathrm{P}$ - average, $\mathrm{N}-$ low; $\%$ max $-\%$ of maximum values of synthetic measure of socio-economic development

Source: own compilation on the basis of data from the GUS (Central Statistical Office) Local Data Bank.

Analysis of the internal differences in the level of socio-economic development conducted in the group of the 18 regional centres only showed greater disproportions among them. In 2013, the development level was high in Warsaw, Wrocław, Poznań and Cracow; for the last three centres this meant an advance over 2004 from the average class (Tab. 1). In turn, in 2013 there were nine centres at an average level of socio-economic development, as against five in 2004. Among them, Gdańsk and Katowice kept their former positions, while Lublin, Olsztyn, Opole, Rzeszów, Szczecin, Torun and Zielona Góra recorded a rise from a low level. The most difficult situation was observed 
in five centres included in the class of a low level of socio-economic development in both 2004 and 2013: Białystok, Bydgoszcz, Gorzów Wlkp., Kielce and Łódź.

The above regularities and tendencies demonstrate that over the years 2004-2013 the position of the regional centres in relation to all poviats in Poland changed only slightly. Still, the differences within the group of the 18 regional centres can be observed to have increased. While the distance between Warsaw and the subsequent centres in the ranking (Poznań in 2004, Wrocław in 2013) was smaller than in relation to all poviats in Poland, the one between Warsaw and the regional centre at the lowest level of socio-economic development (Bydgoszcz in 2004, Gorzów Wlkp. and Łódź in 2013) increased. In 2013, Wrocław attained 67.2\% of the index for Warsaw (in 2004, Poznań attained 64.9\%) against all poviats, but $77.7 \%$ when measured only against the 18 regional centres (in 2004, Poznań - 76.1\%). In turn, in 2013 Gorzów Wlkp., ranked at 44th position against all poviats in Poland, attained a mere $37.5 \%$ of the Warsaw index, while Łódź, the last in classification against the 18 regional centres, achieved $25.1 \%$ of the Warsaw index. The results obtained confirm the dominant role of the largest cities in shaping the country's level of socio-economic development. In 2013, the first five places on the scale of socio-economic development were occupied by Warsaw, Wrocław, Poznań, Cracow and Gdańsk, respectively. The leaders of the list of poviats at the highest development level were also those that together with voivodeship cities form large urban agglomerations, e.g. the poviat-ranking towns of Sopot and Gdynia (6th and 12th places); Piaseczno, Pruszków and Western Warsaw poviats (8th, 17th, and 19th position); or Wrocław poviat (10th). In turn, poviats peripheral to the largest urban centres displayed the lowest level of socio-economic development. Thus, while the differences in the set of all poviats hardly narrowed in a global approach, in the intra-regional approach one can see growing disproportions between the centre of a region (the regional centre and its immediate surroundings) and its peripheries. This phenomenon can be observed in all voivodeships in Poland.

\section{Analysis of the amount and structure of European funds gained by the regional centres}

When analysing the two programming periods, it is readily visible that the regional centres obtained a decided majority of the EU funds in the 2007-2013 perspective. The average proportion of projects funded in this period exceeded $90 \%$ of all the funds absorbed (Fig. 2).

The regional centres differed widely in terms of value of the implemented project. This is especially clear when analysing the absolute figures (Fig. 2). The largest funds of PLN 55.7 billion were allocated to Warsaw, whereas the smallest ones of PLN 2.3 billion to Opole (apart from Zielona Góra, which, together with Gorzów Wlkp., is a dual authority centre in their region). The other regional centres with relatively high values of implemented projects included Poznań, Gdańsk, Cracow, Łódź and Wrocław, while the lowest figures were recorded in Olsztyn, Kielce, Zielona Góra and Gorzów Wlkp.

The differences among the regional centres narrowed visibly when the figures were analysed against the number of residents (Fig. 2). Here the leaders were Gorzów Wlkp., Gdańsk, Katowice and Warsaw, with over PLN 30 thous. zlotys per capita. The lowest values were recorded in Bydgoszcz, Białystok and Zielona Góra, not exceeding PLN 20 thous. per capita. 


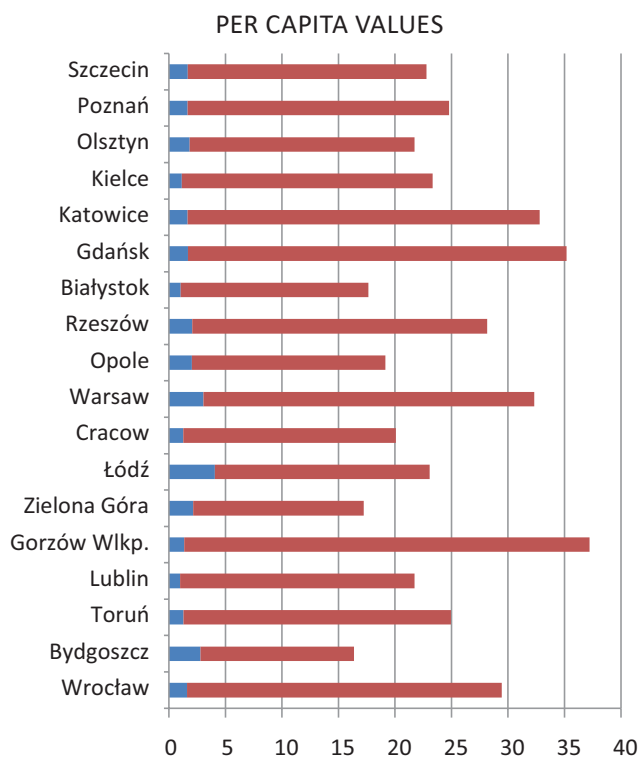

12004-2006 2007-2013 [thous. PLN per capita]

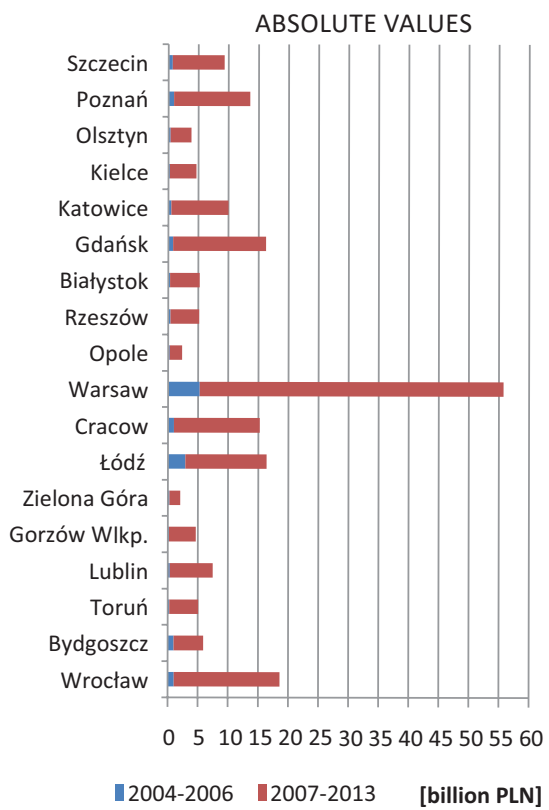

Figure 2. Values of projects co-financed from EU funds in the regional centres in the years 2004-2013 Source: own calculations on the basis of www.mapadotacji.gov.pl (accessed 30 Sept. 2015).

In terms of the obtained EU funds, the dominant role in the structure of projects was played by the European Regional Development Fund (ERDF) and the Cohesion Fund (CF), usually supporting expensive infrastructural investments. Within the framework of those funds, the projects of a total value of PLN 196 billion were carried out in the regional centres (PLN 100 billion from the ERDF and PLN 96 billion from the CF). Those figures covered over $97 \%$ of the total project value. Projects co-financed from the European Social Fund (ESF) amounted to PLN 5 billion (3\% of the total). Since the share of the ERDF and CF in the financing of projects was found to be predominant in all the regional centres, no detailed characterisation of the fund structure for the individual cities is given here, the more that it is reflected in the structure of operational programmes usually financed from a single structural fund. Most of the operational programmes were financed from the ERDF, only the Sectoral Operational Programme of Human Resources Development (SOP HRD), the Human Capital Operational Programme (HC OP) and part of the Integrated Operational Programme of Regional Development (IOPRD) were financed from the ESF.

The operational programme in the framework of which beneficiaries in the regional centres carried out the greatest projects was the Infrastructure and Environment OP (I\&E OP). Its domination is especially readily visible in terms of absolute values (Fig. 3). Warsaw with its projects totalling to PLN 37 billion stands out clearly against the remaining centres; the next-ranked cities, viz. Gdańsk and Wrocław, expended PLN 12 and 11 billion, respectively. The differences between the regional centres were very wide. The value of projects implemented in Olsztyn, Zielona Góra and Opole was not even one-tenth of the Gdańsk and Wrocław figures (PLN 0.3; 0.5 and 0.7 billion zlotys). In terms of per capita values, the shares of the major operational programmes mentioned above stand out even more clearly (Fig. 3). What changed, however, is the ranking of the regional centres. In the case of I\&E OP, Warsaw continued to place itself at the top of the list with PLN 21.5 thous. per capita, 
however it was overtaken by Gdańsk (PLN 26.2 thous. per capita) and, interestingly enough, Gorzów Wlkp. (PLN 29.4 thous.). The two regional centres of Lubuska Land (Gorzów Wlkp. and Zielona Góra) differed greatly in this respect with per capita value of I\&E OP projects carried out in Zielona Góra amounting to a mere PLN 4 thous. Lower values were observed only in Lublin, Białystok and Olsztyn. However, it should be kept in mind that those are regional centres implementing a substantial part of infrastructural investment in the framework of the Development of Eastern Poland OP.
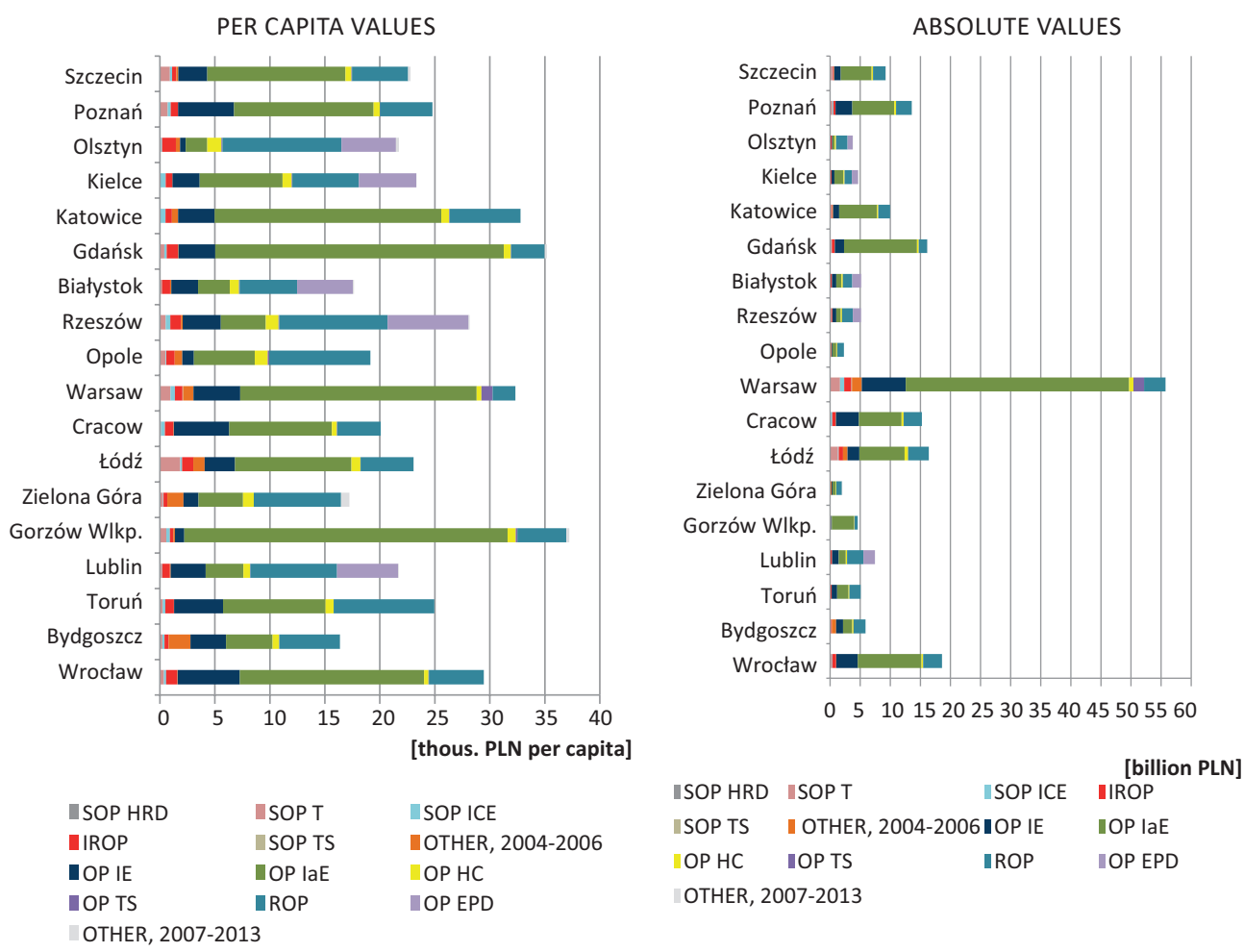

Figure 3. Structure of the values of projects implemented in the regional centres, by operational programme Source: own calculations on the basis of www.mapadotacji.gov.pl (accessed 30 Sept. 2015).

The last aspect to be examined was the fields of intervention in terms of 16 categories found in the EU Subsidies Map database. The category taking up a very high proportion of intervention in vastmajority of the regional centres was transport (Fig. 4). This included both, large road investments and highly expensive projects connected with public transport. Transport projects accounted on average for more than $41 \%$ of the value of all projects, although in Bydgoszcz, Opole, Lublin and Rzeszów their value amounted to less than 30\% of the total (from PLN 0.4 billion in Opole to PLN 1.7 billion in Bydgoszcz). In turn, in Łódź, Gorzów Wlkp. and Warsaw the share of transport projects exceeded 50\% (from PLN 3.5 billion in Gorzów Wlkp. to PLN 36 billion in Warsaw). The remaining intervention categories took up a decidedly lower proportions in the value structure of projects with the major fields including research and development ( $13.6 \%$ on average), business development ( $8.4 \%$ on average) and environmental protection ( $8.3 \%$ on average). In turn, the categories of marginal importance, sometimes not figuring in the structures of the 18 cities at all, comprised of 
security (addressing, e.g., flood prevention and the purchase of equipment for emergency services) and foreign cooperation (Fig. 4).
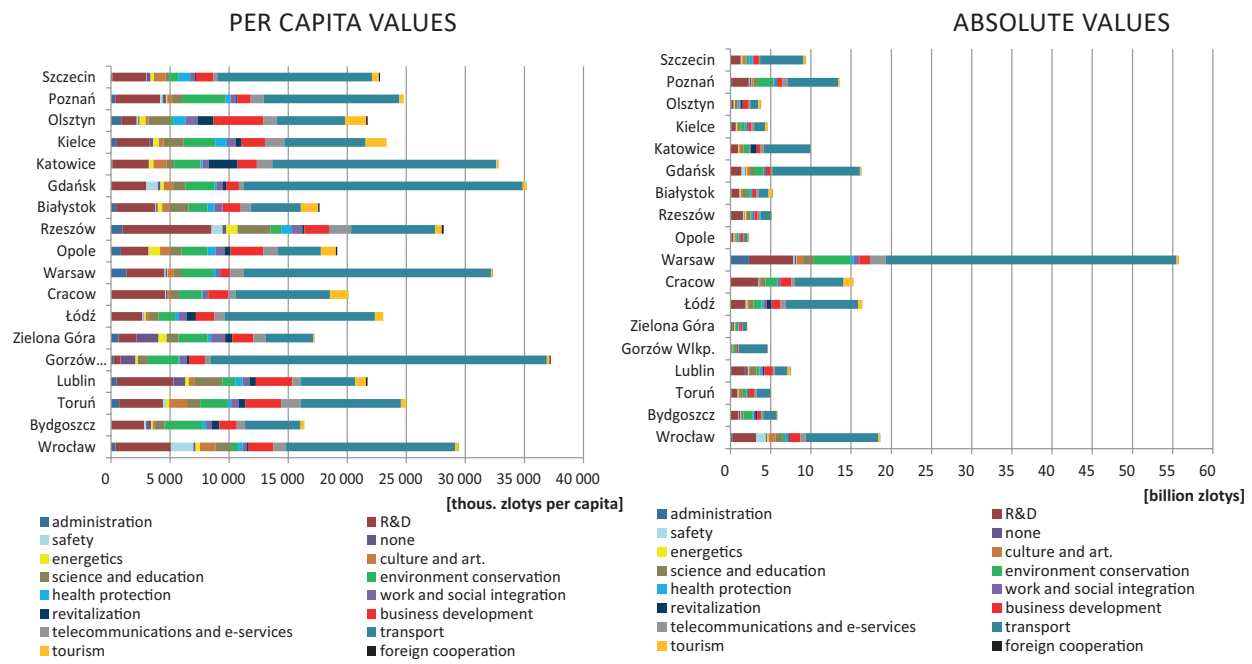

Figure 4. Structure of the values of projects implemented in the regional centres, by intervention category Source: Own calculations on the basis of www.mapadotacji.gov.pl (accessed 30 Sept. 2015).

\section{Place of regional centres in the absorption of European means in regions}

Determining the role of regional centres in absorption of the EU funds seen in relation to the regions was conducted in terms of the number, value and structure of projects.

The share of regional centres in the total number of projects implemented in a region in the entire study period ranged from $7 \%$ in Gorzów Wlkp. and Katowice to $22 \%$ in Warsaw (Fig. 5). It should be emphasised that the positions of Gorzów Wlkp. and Katowice are not fully comparable. The former, together with Zielona Góra, makes up the bipolar regional system of Lubuska Land. Katowice, in turn, is the principal city of the Silesian voivodeship, but also a part of the Upper Silesian conurbation. Hence those two cities are not the places of such high concentration of projects as the capitals of other regions. Warsaw had the largest share in the number of projects implemented in its region. This corroborates its above-average position in the country's socio-economic system connected with a heavy concentration of economic entities and therefore the beneficiaries of the EU funds in this city. It is especially readily visible against the Mazovia region, highly diversified in terms of development. In the examined regional centres, ratio of the number of projects to the population number indicates a high level of co-occurrence of those two variables $(r=0.739$, at $p=0.05)$.

Even higher concentration figures can be found in the case of share of the regional centres in the value of projects implemented in a region. They vary from 12\% in Olsztyn and Rzeszów (voivodeship capitals in the weakest economically eastern part of Poland) to $51 \%$ in Warsaw, which domination in Mazovia and in Poland is much greater than in the number of projects (Fig. 5). The value of projects shows a high level of co-occurrence with the population number $(r=0.848$, at $p=0.05$ ). 
This leads to the conclusion that the level of concentration of EU projects in the regional centre / region system significantly coincides with population density and socio-economic differences. Seen against their regions, regional centres having the highest levels of population density and being the cores of socio-economic development are the places of concentration of relatively the most expensive European projects.

The share of regional centres in the value of the EU funds absorbed in the regions increased steeply in the second EU budgetary perspective (Fig. 5). The only exceptions were Bydgoszcz and Zielona Góra, which recorded a minimum drop in the share. The values of the location quotient defining the concentration of project values in the regional centres corroborate this dependence. Most regional centres recorded a 'deficit' in the values of projects obtained in the 2004-2006 perspective in relation to their share in population number of a region. The only cities where this dependence did not appear were Łódź and Rzeszów. In the second perspective (2007-2013), all the regional centres had a 'surplus' in the values of their European projects in relation to their population density figures. This corroborates their domination in the absorption of those funds in the regions.

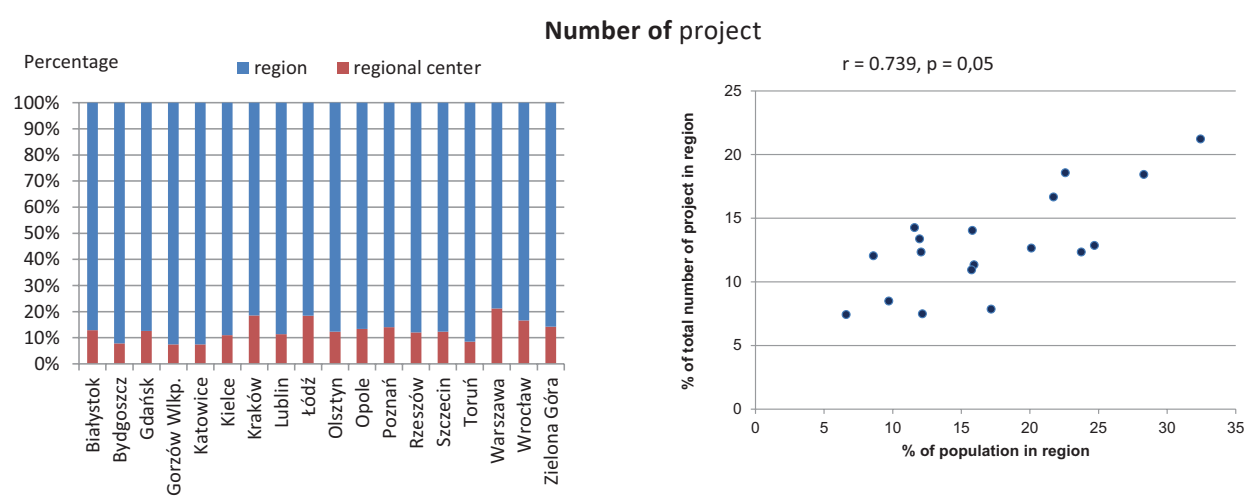

Value of project in periods: 2004-2006 and 2007-2013
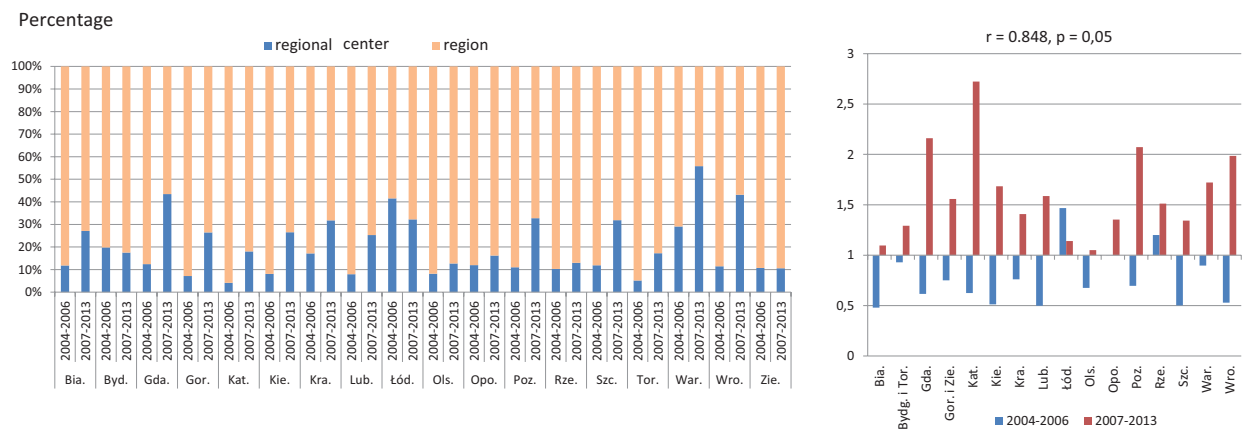

Figure 5. Share of the regional centres in the absorption of EU means in a region - number and value Source: Own calculations on the basis of www.mapadotacji.gov.pl (accessed 30 Sept. 2015).

The share of regional centres in the implementation of European projects in relation to regions shows significant differences in terms of funds and programmes that were the sources of their 
financing. When analysing the two structural funds: ERDF and ESF, and the complementary CF, one can see their specificity resulting from the intervention field targeted. The concentration of ERDF- and CF-financed projects in the regional centres is higher than of those financed from the ESF. The first two funds support, e.g., high-input investment ventures the scale and value of which determine their implementation in the areas enjoying the best financial situation, but at the same time displaying the greatest inefficiency of infrastructural systems, which include the voivodeship capitals. This means the necessity of securing their own input financed from the local budgets which, in the case of the largest projects, can surpass the possibilities of smaller local governments. As a result, the concentration of ERDF funds in the regional centres varies from $10 \%$ in Gorzów Wlkp. to $45 \%$ in Warsaw (Fig. 6). In the case of the $\mathrm{CF}$, the figures are even higher, but range wider, from $1 \%$ in Olsztyn to $63 \%$ in Warsaw (26\% on average). The situation is different in the case of the ESF, being a source financing primarily 'soft' projects with relatively smaller budgets intended to improve the situation on the labour market. Its availability to the peripheral areas is higher, which results in lower concentration of project values in the voivodeship capitals. In consequence, concentration of values of the ESF-financed projects in Katowice was a mere 5\%, and in 18\% Łódź, with an average of $9 \%$ (Fig. 6). In accordance with the above regularities, the location quotient values for the regional centres usually show a 'surplus' in the concentration of values of projects financed from ERDF and CF, and a 'deficit' in the case of ESF. Those tendencies are also corroborated by the structure of project values analysed in terms of operational programmes involved. The highest levels of concentration in the regional centres characterise the projects under programmes supporting high-input investment ventures, and the lowest onesunder those intended to support human and social capital. In the years 2004-2006, the highest concentrations and 'surpluses' were found in the projects implemented within the framework of the Transport Sectoral Operational Programme (T SOP), e.g. in Rzeszów $L Q=10.3$. The lowest concentration figures characterised projects implemented in the SOP HRD framework, e.g. in Białystok $L Q=0.02$. In the years 2007-2013, this tendency continued to prevail. The highest concentrations and 'surpluses' were recorded for projects funded under I\&E OP; e.g. in Katowice $L Q=3.8$, while the lowest concentration figures and 'deficits' were found in OP HCsupported projects; in Wrocław $L Q=0.3$.

To sum up the analysis, the position of regional centres was determined on the scale of concentration of the number and values of projects by intervention category (Fig. 6). The obtained distribution reveals clear regularities. One follows from significant differences in the implementation of projects, especially the investment ones, depending on the financial capabilities of beneficiaries. This allows indicating the regional centres as the areas privileged in obtaining the most generously co-financed European projects. The otherregularity involves differences in the location of individual kinds of socio-economic activity in a region's space. For example, administrative services and activities satisfying higher-order needs tend largely to concentrate in the regional centres. As a result, their highest concentrations can be observed there in the case of European projects connected with administration, culture and art, as well as telecommunications and e-services, whereas the lowest in the case of projects supporting work and social integration as well as revitalisation and the development of firms (Fig. 6). 
Value of project by European funds

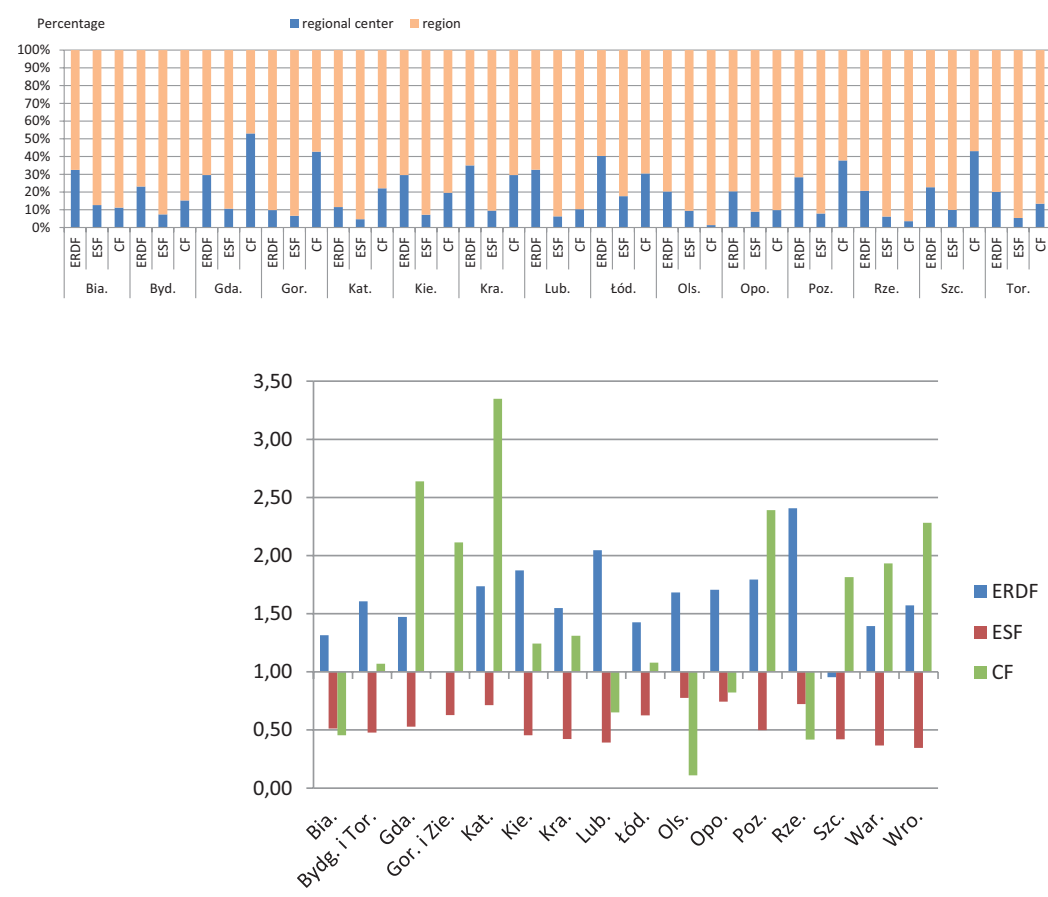

Value of project by intervention category

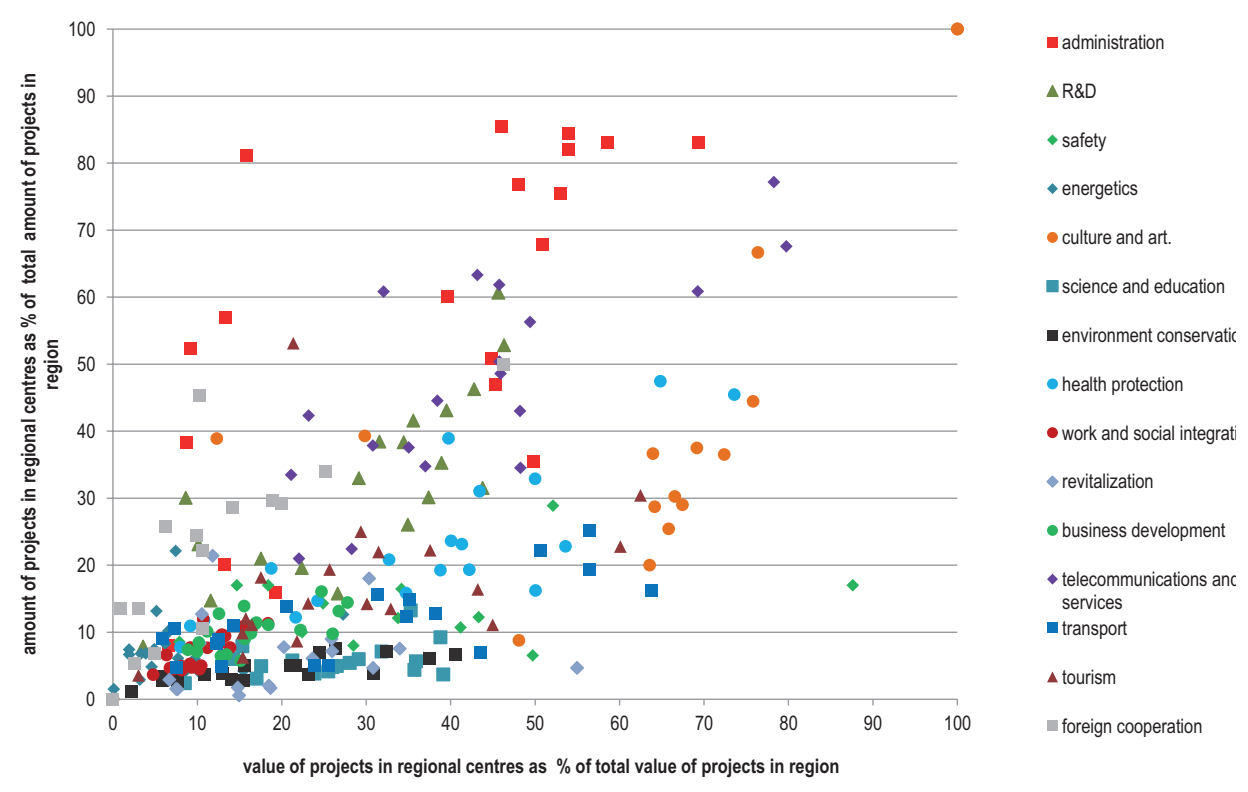

Figure 6. Share of the regional centres in the absorption of EU funds in a region - funds and fields of intervention

Source: own calculations on the basis of www.mapadotacji.gov.pl (accessed 30 Sept. 2015). 


\section{Absorption of EU funds in the regional centres vs. socio- economic development}

Relation between the amount of the EU funds absorbed and the level of socio-economic development of the regional centres was examined using correlation and regression analyses. The measures of the EU funds absorption were: (1) share of a regional centre in the total value of EU funds obtained by the region $\left(X_{R E G}\right) ;(2)$ value of the location quotient expressing the concentration of EU funds in a regional centre $\left(X_{L Q}\right) ;(3)$ absolute amount of the EU funds obtained by the beneficiaries located in a regional centre $\left(X_{U E}\right)^{3}$, and (4) per capita amount of the EU funds obtained by a regional centre $\left(X_{P C}\right)$. The measure of socio-economic development was the synthetic index $v_{i}$, determined in the first stage of the research procedure, in relation to both all poviats in Poland and the 18 regional centres.

The analysis of Pearson's linear correlation coefficients showed the presence ofclose and statistically significant covariance between the level of the socio-economic development of a regional centre on the one hand and its share in the total EU funds obtained by its region $\left(X_{R E G}\right)$ and their absolute value in the region $\left(X_{U E}\right)$ on the other hand (Tab. 2). The remaining relations exhibited a low level of correlation and no statistical significance (at $p<0.05$ ). This held for the level of socio-economic development determined for both all poviats in Poland and the group of 18 cities. In the first case the correlation coefficients were much higher, which suggests that the amount of the EU funds absorbed was more closely correlated with the level of socio-economic development determined in relation to all poviats in the country than with the internal differences in the group of cities. Hence a simple linear regression analysis was made of the dependence between the level of socio-economic development and the absorption expressed only by those two measures: $X_{R E G}$ and $X_{U E}$. As a result, the following equations were obtained:

The effect of share of a regional centre in the absorption of EU funds obtained by a region on the level of socio-economic development of the centre:

- in relation to 379 poviats:

$\mathrm{PR}_{2013-379}=0.154+0.005 \mathrm{X}_{\mathrm{REG}} \pm 0.056 ; \mathrm{R}^{2}=0.522 ; \mathrm{p}<0,001$

- in relation to the 18 cities:

$$
\mathrm{PR}_{2013-18}=0.180+0.006 \mathrm{X}_{\mathrm{REG}} \pm 0.108 ; \mathrm{R}^{2}=0.286 ; \mathrm{p}<0,022
$$

The effect of absolute value of the EU funds absorbed by the regional centres on their level of socio-economic development:

- in relation to 379 poviats:

$\mathrm{PR}_{2013-379}=0.217+0.000 \mathrm{X}_{\mathrm{UE}} \pm 0.033 ; \mathrm{R}^{2}=0.837 ; \mathrm{p}<0,000$

- in relation to the 18 cities:

$$
\mathrm{PR}_{2013-18}=0.250+0.000 \mathrm{X}_{\mathrm{UE}} \pm 0.089 ; \mathrm{R}^{2}=0.509 ; \mathrm{p}<0,001
$$

3 The use of absolute values is necessary to eliminate a statistical effect involving the relation between an absolute and per capita value of an investment and its efficiency in the areas with a high and a low population density. 
Table 2. Level of socio-economic development and selected indices of the amount of EU fundss absorbed by the regional centres in Poland in 2013

\begin{tabular}{|c|c|c|c|c|}
\hline \multirow[b]{2}{*}{$\begin{array}{l}\text { level of socio- } \\
\text { economic } \\
\text { development }\end{array}$} & $X_{R E G}$ & $x_{L Q}$ & $x_{U E}$ & $X_{P C}$ \\
\hline & $\begin{array}{l}\text { share of regional } \\
\text { centre in EU funds in } \\
\text { region }\end{array}$ & $\begin{array}{l}\text { location quotient } \\
(L Q) \text { of EU funds in } \\
\text { regional centre }\end{array}$ & $\begin{array}{l}\text { absolute value of EU } \\
\text { funds obtained by } \\
\text { regional centre }\end{array}$ & $\begin{array}{c}\text { means per capita } \\
\text { obtained by regional } \\
\text { centre }\end{array}$ \\
\hline \multirow{2}{*}{$\begin{array}{l}P R_{2013-379}: \text { in } \\
\text { relation to } 379 \\
\text { poviats }\end{array}$} & 0.723 & 0.302 & 0.915 & 0.352 \\
\hline & $p=0.001$ & $p=0.223$ & $p=0.000$ & $p=0.152$ \\
\hline \multirow{2}{*}{$\begin{array}{l}P R_{2013-18}: \text { in relation } \\
\text { to } 18 \text { cities }\end{array}$} & 0.535 & 0.406 & 0.713 & 0.362 \\
\hline & $p=0.022$ & $p=0.094$ & $p=0.001$ & $p=0.140$ \\
\hline
\end{tabular}

Source: own compilation on the basis of data from the GUS Local Data Bank.

The best fit of the regression models can be found when the level of socio-economic development of the regional centres is determined in relation to all poviats in Poland. The fraction of variance explained by a model (on the basis of coefficient of determination $\mathrm{R}^{2}$ ) was greater in the case of explanatory variable being the absolute value of the EU funds obtained (for $X_{U E} \mathrm{R}^{2}=0.837$ ) than in the case of explanatory variable being the share of a regional centre in the total EU funds absorbed by a region (for $X_{R E G} R^{2}=0.522$ ). It can therefore be assumed that the absolute value of the EU funds obtained by a regional centre accounts best for its level of socio-economic development determined in relation to all poviats in Poland. Hence one can conclude that there is a good fit of the amount of the EU funds absorbed in the regional centres to their level of socio-economic development measured against all poviats in Poland.

Table 3. Level of socio-economic development and the absorption of EU funds by the regional centres in Poland in 2013

\begin{tabular}{|c|c|c|c|c|}
\hline \multirow{2}{*}{\multicolumn{2}{|c|}{$\begin{array}{l}\text { in relation to } \\
379 \text { poviats }\end{array}$}} & \multicolumn{3}{|c|}{ Level of socio-economic development in 2013.} \\
\hline & & HIGH & AVERAGE & LOW \\
\hline \multirow{3}{*}{ 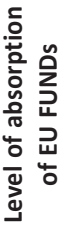 } & $\mathrm{HIGH}$ & Warsaw & & \\
\hline & AVERAGE & $\begin{array}{c}\text { Cracow, Poznań, } \\
\text { Wrocław }\end{array}$ & Gdańsk, Łódź & \\
\hline & LOW & & $\begin{array}{c}\text { Białystok, Katowice, Lublin, Olsztyn, } \\
\text { Opole, Rzeszów, Szczecin, Toruń, } \\
\text { Zielona Góra }\end{array}$ & $\begin{array}{l}\text { Bydgoszcz, Gorzów } \\
\text { Wlkp., Kielce }\end{array}$ \\
\hline \multirow{2}{*}{\multicolumn{2}{|c|}{$\begin{array}{l}\text { in relation to } \\
18 \text { cities }\end{array}$}} & \multicolumn{3}{|c|}{ Level of socio-economic development in 2013.} \\
\hline & & HIGH & AVERAGE & LOW \\
\hline \multirow{3}{*}{ 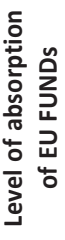 } & HIGH & Warsaw & & \\
\hline & AVERAGE & $\begin{array}{c}\text { Cracow, Poznań, } \\
\text { Wrocław }\end{array}$ & Gdańsk & Łódź \\
\hline & LOW & & $\begin{array}{c}\text { Katowice, Lublin, Olsztyn, Opole, } \\
\text { Rzeszów, Szczecin, Toruń, Zielona } \\
\text { Góra }\end{array}$ & $\begin{array}{l}\text { Białystok, Bydgoszcz, } \\
\text { Gorzów Wlkp., Kielce }\end{array}$ \\
\hline
\end{tabular}

Source: own compilation on the basis of data from the GUS Local Data Bank. 
What corroborated this conclusion was an analysis of the standardised residuals from regression (normal distribution, no autocorrelation of random components - the Durbin-Watson test $d \approx 2$ ) for the models with the explanatory variables being both $X_{R E G}$ and $X_{U E}$ (Fig. 7). In this case, greater explanatory power of the model with the variable $X_{U E}$ calls for a closer look at the distribution of residuals from regression. In such regional centres as Poznań, Cracow and Wrocław, higher level of socio-economic development in relation to the concentration of EU funds than would follow from the model (positive residuals) is readily visible. In turn, in Łódź, Bydgoszcz, Gorzów Wlkp. and Kielce the level of socio-economic development was lower than would follow from the regression model as a result of the EU funds absorbed. This leads to the conclusion that the first group made a more efficient use of the EU funds, which reinforced the development-related effect and manifested itself in their higher level of socio-economic development. In the other group, the absorption of EU funds hand no such a significant effect on their development. Naturally, it should be kept in mind that those regularities could be caused by other factors moulding the development of the individual regional centres, not accommodated in the model.

To summarize, the best fit between the level of socio-economic development and the amount of the EU funds absorbed was found in Warsaw, Gdańsk, Bydgoszcz, Gorzów Wlkp. and Kielce (Table 3). In turn, the differences between the level of socio-economic development and the amount of the EU funds absorbed were the widest when the development level was higher than the absorption level, e.g. in Katowice, Lublin, Olsztyn, Opole and Rzeszów.

\section{Conclusions}

The performed research shows that the regional centres in Poland have a dominant position in the process of absorption of the EU funds. The results obtained enable verification of the research hypotheses and formulating the most important conclusions and recommendations for a development policy.

The regional centres, irrespective of their position in the country, are the areas exhibiting the highest level of socio-economic development in the intra-regional system. In the study period, they kept their high position on the scale of socio-economic development. Together with these poviats where large industrial entities are located, they are the growth poles in the Polish socio-economic space. The reinforcement of their position was especially readily visible against all poviats in Poland, while in relation to the group itself this process was less conspicuous. This was due to the fact that the positions of Gorzów Wlkp., Zielona Góra, Olsztyn, Opole and Łódź dropped on the development scale, both in the poviat system and within the group of the 18 cities. This means that socio-economic development was more dynamic in larger regional centres and those with a more diversified structure of economic activity. Thus, a high level of spatial polarisation of socio-economic development and wide differences in the branch-related concentration of economic activity are significant factors shaping the development pattern of the regional centres in Poland.

The level of absorption of the EU funds, while high in the regional centres, shows significant differences in terms of the programming periods, types of Community funds and operational programmes involved and intervention categories. Concentration of the EU funds absorbed is considerable in the centres. These are the places of implementation of $7 \%$ to $21 \%$ of the total number of projects in a region, and their value varies from $12 \%$ to $51 \%$ of the total allocation there. This concentration figures grew significantly in the years $2007-2013$, often exceeding $40 \%$ 
(Warsaw, Gdańsk, Wrocław, Łódź) inthe regional centres being the places attracting the largest infrastructural projects inaccessible - because of their great costs - to economically weaker entities located outside the centres. ERDF, CF and I\&E OP are predominant in the structure of funds and programmes, providing support for this kind of investment. This regularity is also corroborated by the absorption structure in terms of intervention fields. The projects connected with functions performed by the regional centres (e.g. administration as well as culture and art) are followed by these connected with transport and environmental protection. High concentration of EU funds in the regional centres is indicative for a relatively high level of efficiency of their spending that results from high population density in those areas, as noted, e.g., by Rodríguez-Pose and Garcilazo (2015). The above demonstrates a change in the Polish regional policy, not intended at the programming stage, especially in the scale of concentration of the EU funds. This complies with a change in the regional policy paradigm, hence with the transition from equalisation to efficiency (Bachtler 2001; Soja 2010; Storper 2011).

The amount of the EU funds absorbed in the regional centres is more closely connected with their level of socio-economic development in relation to all poviats in Poland than that within the group. In this case the situation is more diversified and reveals certain regularities. The analysis of residuals from regression shows that in such centres as Poznań, Cracow and Wrocław the development-related effects of the EU funds absorbed were greater and produced a higher level of socio-economic development, while in Łódź, Bydgoszcz and Gorzów Wlkp., despite their relatively high level of absorption, those effects were smaller, as reflected by their lower development levels.

To sum up, the regional centres in Poland have been found to be the areas of a higher concentration of the EU funds absorbed than would follow from the assumptions of the development policy. The implemented intervention contributes primarily to improving the living conditions and to creating better conditions for business. Persistent concentration of EU funds in the regional centres can contribute to higher efficiency of their use, but on the other hand it can lead to deepening of differences in the intra-regional development. In our opinion, the development policy in Poland should now focus on creating the conditions for the reinforcement of development diffusion. Using the assumptions of a place-based policy will require:

- better identification of the territorial specificity of a region to create the conditions for better cooperation of the regional centre with its immediate and farther surroundings, which should be stimulated by the voivodeship's self-government as the part of its intra-regional policy,

- development of instruments promoting the integration of measures taken, including expansion of the Integrated Territorial Investments formula, which is the remit of entities conducting inter-regional policy at the supra-national and national levels, and

- ensuring proper legal backup for the above measures, e.g. the Metropolitan Associations Act of 27 October 2015, signed by the President of the Republic of Poland on 27 October 2015 (Act of ..., 2015).

\section{Acknowledgements}

We wish to thank the participants of the Warsaw Regional Forum organised in October 2015 by the Institute of Geography and Spatial Organisation of the Polish Academy of Sciences in Warsaw for their valuable comments during the discussion and an informal exchange of opinions that allowed us to give a clearer explanation of the identified regularities and hence to improve their presentation here. 


\section{References}

Amiti M., Cameron L., 2007. Economic Geography and Wages. Review of Economics and Statistics, vol. 89(1), pp. 15-29.

Bachtler J., 2001. Where is regional policy going? Changing concept of regional policy. European Policies Research Centre, Glasgow: University of Strathclyde.

Bachtler J., Ferry M., 2015. Conditionalities and the Performance of European Structural Funds: A Principal-Agent Analysis of Control Mechanisms in European Union Cohesion Policy. Regional Studies, vol 49(8), pp. 1258-1273.

Barca F., 2009. An Agenda for a Reformed Cohesion Policy, A place-based approach to meeting European Union challenges and expectations. Independent Report.

Baum-Snow, N., Pavan R., 2012. Understanding the City Size Wage Gap. Review of Economic Studies, vol. 79(1), pp. 88-127.

Behrens K., Duranton G., Robert-Nicoud F., 2014. Productive Cities: Sorting, Selection, and Agglomeration. Journal of Political Economy, vol. 122(3), pp. 507-553.

Camagni R., 2008. Towards a Concept of Territorial Capital [in:] R. Capello, R. Camagni, B. Chizzolini, U. Fratesi (eds.), Modelling regional scenarios for the enlarged Europe. Berlin: Springer, pp. 33-47. Chudzik H., Karoński M., 1979. Skupianie obserwacji metodq k-średnich. Roczniki Akademii Rolniczej w Poznaniu, Algorytmy Biometryczne i Statystyczne, vol. 8 (78), pp. 133-152.

Duranton, G., 2014. Growing Through Cities in Developing Countries. World Bank Research Observer, 2014, Policy Working Paper No. 6818, March 2014.

Foreman-Peck J.S., Gripaios, P.A., 1977. Inner city problems and inner city policies. Regional Studies, vol. 11(6), pp. 401-412.

Hellwig Z., 1968. Zastosowanie metody taksonomicznej do typologicznego podziału krajów ze względu na poziom ich rozwoju oraz zasoby i strukturę wykwalifikowanych kadr. Przegląd Statystyczny, vol. 4, pp. 307-327.

Hellwig Z., 1981. Wielowymiarowa analiza porównawcza i jej zastosowanie w badaniach wielocechowych obiektów gospodarczych [in:] W. Welfe (ed.), Metody i modele ekonomiczno-matematyczne w doskonaleniu zarządzania gospodarką socjalistyczną, Warszawa: PWE, pp. 46-68.

Hidle K., Leknes E., 2014. Policy Strategies for New Regionalism: Different Spatial Logics for Cultural and Business Policies in Norwegian City Regions. European Planning Studies, vol. 22(1), pp. 126-142. Jacobs J. 1969. The Economy of Cities. New York: Random House.

Krajowa Polityka Miejska, 2015. Warszawa: Ministerstwo Infrastruktury i Rozwoju.

Mac Queen J., 1966. Some methods for classification and analysis of multivariate observations. Proceedings of the Fifth Barkeley Symposium on Mathematical Statistics and Probability, vol. 1 Statistics. Barkeley: University of California Press, pp. 281-287.

Mallach A., 2014. The Uncoupling of the Economic City: Increasing Spatial and Economic Polarization in American Older Industrial Cities, Urban Affairs Review, June 2014.

Maynou L., Saez M., Kyriakou A., Bacaria J., 2014. The Impact of Structural and Cohesion Funds on Eurozone Convergence, 1990-2010. Regional Studies, vol. 9, pp. 1-13.

Nowak E., 1990. Metody taksonomiczne w klasyfikacji obiektów społeczno-gospodarczych. Warszawa: PWE.

Reshaping Economic Geography. World Development Report, 2009, Washington. 
Rodríguez-Pose A., Garcilazo E., 2015. Quality of Government and the Returns of Investment: Examining the Impact of Cohesion Expenditure in European Regions. Regional Studies, vol. 49(8), pp. 1274-1290.

Soja E.W., 2010. Seeking Spatial Justice. Minneapolis: University of Minnesota Press.

Storper M., 2011. Justice, efficiency and economic geography: should places help one another to develop? European Urban and Regional Studies, vol. 18(1), pp. 3-21.

Suchecki B., 2010. Ekonometria przestrzenna. Metody i modele analizy danych przestrzennych. Warszawa: Wydawnictwo C. H. Beck.

Townsend A.R., 1977. The relationship of inner city problems to regional policy. Regional Studies, vol. 11(4), pp. 225-251.

Ustawa z dnia 9 października 2015r. o związkach metropolitalnych. Tekst ustawy ustalony ostatecznie po poprawkach Senatu. http://orka.sejm.gov.pl/opinie7.nsf/nazwa/2107_u/\$file/2107_u.pdf [27 October 2015].

Zaucha J., Komornicki T., 2015. The Concept of Territorial Cohesion as Understood and Practiced by Polish Regions. Working Papers 2/2015, Sopot: Institute for Development.

(c) (i) 